\title{
Deoxyribonucleic Acid Base Composition in the Genus Pseudomonas
}

\author{
BY M. MANDEL \\ Section of Molecular Biology, Department of Biology, The University of Texas, \\ M. D. Anderson Hospital and Tumor Institute, Houston, Texas
}

(Received 21 October 1965)

\section{SUMMARY}

The base compositions of deoxyribonucleic acids extracted from aerobic pseudomonads were determined by examination of the buoyant density of each sample in caesium chloride $(\mathrm{CsCl})$ gradients. A collection of 165 strains, representing many of the principal biotypes among aerobic pseudomonads, was subjected to this examination. The similarities and differences in the base compositions of the genetic material have been compared with the taxonomic arrangements suggested by the comparison of phenotypic (largely nutritional and enzymic) features. The data on base composition of the deoxyribonucleic acids of the various cultures support, for the greater part, the conclusions of Stanier, Palleroni \& Doudoroff (1966) and of Redfearn, Palleroni \& Stanier (1966). Data are also presented on pseudomonads not included in the latter studies.

\section{INTRODUCTION}

Taxonomic groupings, if presented as representing natural groupings of organisms by virtue of common descent or heritage, should demonstrate some uniformity of genetic capacity. Evidence of this sort has proved quite difficult to obtain within the microbial world. A recent review of this evidence (Marmur, Falkow \& Mandel, 1963 $a$ ) indicates the limits which the paucity of known genetic mechanisms have placed upon the application of biological hybridization as a tool in bacterial taxonomy. Lee, Wahl \& Barbu (1956) recognized that different bacteria have quite different proportions of the purine and pyrimidine bases present in their deoxyribonucleic acids (DNA). They also recognized that bacterial species and genera which were classified together were more often similar in base composition than were those of greater separation in current schemes of classification. Lanni (1960) proposed that a minimum requirement for genetic exchange was a similarity of base compositions of the DNA of sexual partners. Within the genus Bacillus it was then demonstrated that a necessary, but not sufficient, condition for transformation to occur was identity of base composition (Marmur, Seaman \& Levine, 1963 $b$ ).

Colwell \& Mandel (1964a) showed that groups of Gram-negative bacteria of differing DNA base composition were well separated by the computer groupings of Adansonian analysis. A similar correlation for Gram-positive cocci has been provided by Silvestri \& Hill (1965).

At present, there appears to be no reasonable evidence that the mean DNA base composition of an organism is subject to either induced or spontaneous change within the limits of our gross analytical techniques. Claims to the contrary can be 
attributed to the failure to recognize contamination as such, or to failures in analytical techniques (De Ley, 1964a). We have, therefore, determined the DNA base composition of a large and representative sampling of the strains of pseudomonads reported in the companion papers by Stanier, Palleroni \& Doudoroff (1966) and of representatives of Pseudomonas pseudomallei and $\boldsymbol{P}$. malle $i$ examined by Redfearn, Palleroni \& Stanier (1966). These cultures have been subjected to intensive biochemical characterization, as has been the case for $P$. lemoignei (Delafield et al. 1965).

The DNA base compositions reported in the present communication have been deduced from the buoyant densities determined at equilibrium in a caesium chloride $(\mathrm{CsCl})$ gradient. The choice of the method was dictated by several considerations, of which the large number of samples to be examined was the most demanding. Schildkraut, Marmur \& Doty (1962) pointed out that purified DNA samples are not required for use in this method: consequently, the preparation time of samples is considerably shortened and the nucleic acids are of high molecular weight because of the lessened risk of shear incidental to increased manipulation during purification. A further advantage of the technique is that only small amounts of material are required for analysis. The disadvantages are that the determinations lack some of the precision of comparisons obtainable by means of optical absorbance changes as a function of temperature. Offsetting this additional precision is the danger of recording spurious melting temperatures as a consequence of inequalities in ionic strength, presence of heavy metals or polyamines as contaminants of the preparations (Schildkraut \& Lifson, 1965; Mandel, 1962). Although the presence of an unusual base replacing either thymine or cytosine and glycosylation of the constituent bases may lead to density determinations higher than those predicted by knowledge of the base compositions of the DNA (Schildkraut et al. 1962), thus far no such anomaly has been found in any DNA sample isolated from a bacterial source. Reports of discrepancies between base composition determined by melting temperature and buoyant density (Frontali, Hill \& Silvestri, 1965) are probably attributable to the uncertainty of the linearity of the relationships of melting temperature to base composition at extreme ratios of guanine+cytosine to adenine + thymine (Marmur \& Doty, 1962; Colwell \& Mandel, 1964a). The determination of buoyant density of DNA samples can consequently be used with confidence to assay reproducibly a large number of samples for comparative estimates of base composition. Additionally, the technique has the bonus advantage of revealing non-Gaussian distributions of molecules in the gradient if this departure is evident (as will be shown for the DNA of two strains of Pseudomonas stutzeri). Forty-four replicate determinations of the buoyant density in $\mathrm{CsCl}$ of one sample of DNA extracted from a strain of Caulobacter crescentus averaged $1.7255 \mathrm{~g} . / \mathrm{cm} .{ }^{3}$ with a standard deviation of $0.0005 \mathrm{~g} . / \mathrm{cm} .{ }^{3}$ and a standard error of less than $0.0001 \mathrm{~g} . / \mathrm{cm} .{ }^{3}$ permitting a convenient comparison with the determinations reported here.

\section{METHODS}

Organisms. The strains examined were received on nutrient agar slopes via airmail from the donors. Usually three slopes were shipped to Texas and a fourth retained at the University of California laboratories for diagnostic examination when 
necessary. Cultures were often identified only as to number, thus eliminating operator bias.

Preparation of $D N A$ samples. Lysates of bacteria were prepared by washing the growth from the surface of the agar slopes with a small amount of saline EDTA $(0 \cdot 15 \mathrm{M}-\mathrm{NaCl}+0 \cdot 1 \mathrm{M}$-ethylenediaminetetra-acetic acid, EDTA; $\mathrm{pH} 8 \cdot 0)$ followed by the addition of sodium lauryl sulphate to $2 \%(\mathrm{w} / \mathrm{v})$. The lysate was deproteinized by shaking with neutralized phenol saturated with saline EDTA, then with chloroform + isoamyl alcohol $(24+1$, by vol.). The nucleic acids were precipitated with 2 vol. of ethanol, collected by spooling on a glass rod, washed twice with $70 \%(\mathrm{v} / \mathrm{v})$ ethanol in water and then dissolved in $0.15 \mathrm{M}-\mathrm{NaCl}$ containing $0.015 \mathrm{M}-\mathrm{Na}_{3}$ citrate (pH 7·0).

Cultures received as lyophilized samples were cultivated in nutrient broth (Difco) at $30^{\circ}$ on a rotary shaker. The cultures were streaked on nutrient agar (Difco) and examined microscopically with phase-contrast optics to assure cultural purity. DNA was isolated and purified by the method of Marmur (1961), following lysis and one deproteinization with phenol as described above. Lysates of Pseudomonas pseudomallei and $P$. malle $i$ were prepared within plastic isolation hoods and removed to the room through a phenol solution only after the addition of phenol to the lysate.

Buoyant density. The buoyant density in $\mathrm{CsCl}$ solutions and the guanine + cytosine (GC) content were determined as described by Schildkraut et al. (1962). Centrifugation was performed in a Spinco Model $\mathrm{E}$ analytical ultracentrifuge at 42,040 rev./ min. and $25 \cdot 0^{\circ}$ for 22-23 hr. Each sample was also analysed by centrifugation in

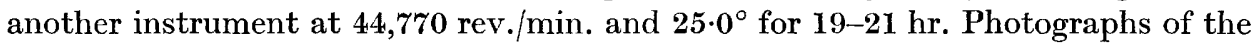
DNA bands at equilibrium in the gradient were obtained on Kodak Ortho Contrast Film by using monochromatic light at $265 \mathrm{~m} \mu$. Each centrifuge cell received approximately 1-2 $\mu \mathrm{g}$. of the DNA of unknown density and $0.5 \mu \mathrm{g}$. of a reference DNA sample from SP 8 bacteriophage (Bacillus subtilis host) of a density of $1.742 \mathrm{~g} . /$ cm..$^{3}$ as calculated by comparison with DNA of Escherichia coli taken to be the primary reference of $1.710 \mathrm{~g} . / \mathrm{cm} .^{3}$. Microdensitometer tracings of the ultraviolet (u.v.) photographs were made with a Joyce-Loebl double-beam recording microdensitometer. The GC content was calculated from the peak of each u.v.-absorbing band by using the equation of Schildkraut et al. (1962).

Values of standard deviations and statistical significance were determined with the aid of an IBM 1620 computer and standard program.

\section{RESULTS}

\section{The fluorescent pseudomonads}

Of the 175 strains studied by Stanier et al. (1966), 66 were analysed for DNA base composition. The mean buoyant density calculated from a minimum of duplicate determinations of the density of the DNA of each strain is listed in Table 1. Each species or biotype, in the terminology of Stanier et al. (1966), appears to be composed of individuals of homogeneous mean DNA base composition. The organisms comprising the species Pseudomonas putida can be divided into two types on the basis of their GC content; biotype A consists of organisms whose mean DNA base composition is $2 \%$ higher in GC content than organisms of biotype $B$ and this difference is significant at the $99 \%$ confidence level (Table 2). Stanier et al. (1966) 
Table 1. Buoyant density and GC content of DNA of representatives of the fluorescent pseudomonads

Values given for mean density are rounded averages of at least two determinations of the buoyant density in $\mathrm{CsCl}$ at 44,770 and 42,040 rev./min. Strain numbers correspond to designations of Stanier et al. (1966).

\begin{tabular}{|c|c|c|c|c|c|}
\hline \multirow[b]{2}{*}{ Species } & \multirow[b]{2}{*}{ Biotype } & \multirow[b]{2}{*}{ Strain } & \multirow{2}{*}{$\begin{array}{l}\text { Mean density } \\
\left(\mathrm{g} \cdot / \mathrm{cm} \cdot{ }^{3}\right)\end{array}$} & \multicolumn{2}{|c|}{ calculated for each group } \\
\hline & & & & Density (g./cm. ${ }^{3}$ ) & GC (moles \%) \\
\hline Pseudomonas aeruginosa & - & $\begin{array}{r}45 \\
52 \\
55 \\
58 \\
131 \\
132 \\
278 \\
280 \\
282 \\
286 \\
291\end{array}$ & $\left.\begin{array}{l}1 \cdot 726 \\
1 \cdot 726 \\
1 \cdot 7255 \\
1 \cdot 726 \\
1 \cdot 727 \\
1 \cdot 726 \\
1 \cdot 725 \\
1 \cdot 725 \\
1 \cdot 726 \\
1 \cdot 7265 \\
1 \cdot 7255\end{array}\right\}$ & $1 \cdot 7259 \pm 0 \cdot 0011$ & $67 \cdot 2 \pm 1 \cdot 1$ \\
\hline \multirow[t]{7}{*}{ P. fluorescens } & $\mathbf{A}$ & $\begin{array}{r}12 \\
126 \\
182 \\
392\end{array}$ & $\left.\begin{array}{l}1.719 \\
1 \cdot 719 \\
1 \cdot 7195 \\
1.7195\end{array}\right\}$ & $1 \cdot 7193 \pm 0 \cdot 0011$ & $60 \cdot 5 \pm 1 \cdot 1$ \\
\hline & $\mathbf{B}$ & $\begin{array}{r}2 \\
400 \\
401 \\
403 \\
404 \\
411\end{array}$ & $\left.\begin{array}{l}1 \cdot 719 \\
1 \cdot 721 \\
1 \cdot 7195 \\
1 \cdot 720 \\
1 \cdot 721 \\
1 \cdot 720\end{array}\right\}$ & $1 \cdot 7201 \pm 0.0011$ & $61 \cdot 3 \pm 1 \cdot 1$ \\
\hline & $\mathbf{C}$ & $\begin{array}{r}18 \\
50 \\
181 \\
191 \\
213 \\
217\end{array}$ & $\left.\begin{array}{l}1 \cdot 7195 \\
1 \cdot 719 \\
1 \cdot 720 \\
1 \cdot 719 \\
1 \cdot 7195 \\
1 \cdot 7195\end{array}\right\}$ & $1 \cdot 7194 \pm 0 \cdot 0008$ & $60 \cdot 6 \pm 0 \cdot 8$ \\
\hline & $\mathbf{D}$ & $\begin{array}{r}\mathbf{3 0} \\
\mathbf{3 1} \\
\mathbf{3 2} \\
\mathbf{3 5} \\
\mathbf{3 8 8} \\
\mathbf{3 8 9} \\
\mathbf{3 9 0} \\
\mathbf{3 9 1} \\
\mathbf{3 9 3} \\
\mathbf{3 9 4}\end{array}$ & $\left.\begin{array}{l}1 \cdot 7215 \\
1 \cdot 722 \\
1 \cdot 722 \\
1 \cdot 7225 \\
1 \cdot 7215 \\
1 \cdot 7225 \\
1 \cdot 722 \\
1 \cdot 7225 \\
1 \cdot 7225 \\
1 \cdot 722\end{array}\right\}$ & $1 \cdot 7222 \pm 0 \cdot 0009$ & $63 \cdot 5 \pm 0 \cdot 9$ \\
\hline & $\mathbf{E}$ & $\begin{array}{l}36 \\
37 \\
38 \\
39 \\
41 \\
86\end{array}$ & $\left.\begin{array}{l}1 \cdot 722 \\
1 \cdot 7215 \\
1 \cdot 7225 \\
1 \cdot 723 \\
1 \cdot 722 \\
1 \cdot 7225\end{array}\right\}$ & $1 \cdot 7223 \pm 0.0008$ & $63 \cdot 6 \pm 0 \cdot 8$ \\
\hline & $\mathbf{F}$ & $\begin{array}{r}83 \\
143\end{array}$ & $\left.\begin{array}{l}1 \cdot 718 \\
1 \cdot 7185\end{array}\right\}$ & $1 \cdot 7182 \pm 0 \cdot 0008$ & $59 \cdot 4 \pm 0 \cdot 8$ \\
\hline & $\mathbf{G}$ & $\begin{array}{r}33 \\
34 \\
267 \\
269 \\
271 \\
272\end{array}$ & $\left.\begin{array}{l}1 \cdot 720 \\
1 \cdot 7195 \\
1 \cdot 7195 \\
1 \cdot 7185 \\
1 \cdot 719 \\
1719\end{array}\right\}$ & $1 \cdot 7193 \pm 0 \cdot 0010$ & $60 \cdot 5 \pm 1 \cdot 0$ \\
\hline
\end{tabular}


Table 1 (cont.)

\begin{tabular}{|c|c|c|c|c|c|}
\hline \multirow[b]{2}{*}{ Species } & \multirow[b]{2}{*}{ Biotype } & \multirow[b]{2}{*}{ Strain } & \multirow[b]{2}{*}{$\begin{array}{l}\text { Mean density } \\
\quad\left(\mathrm{g} \cdot / \mathrm{cm} \cdot{ }^{3}\right)\end{array}$} & \multicolumn{2}{|c|}{$\begin{array}{l}\text { Mean value and standard deviation } \\
\text { calculated for each group }\end{array}$} \\
\hline & & & & $\overbrace{\text { Density (g./cm. }}^{3}$ ) & GC (moles \%) \\
\hline$P \cdot p u t i d a$ & $\mathbf{A}$ & $\begin{array}{r}5 \\
6 \\
7 \\
26 \\
42 \\
90\end{array}$ & $\left.\begin{array}{l}1 \cdot 7205 \\
1 \cdot 722 \\
1 \cdot 721 \\
1 \cdot 7215 \\
1 \cdot 721 \\
1 \cdot 722\end{array}\right\}$ & $1 \cdot 7213 \pm 0 \cdot 0009$ & $62 \cdot 5 \pm 0 \cdot 9$ \\
\hline & B & $\begin{array}{r}53 \\
96 \\
98 \\
110 \\
153 \\
157 \\
158 \\
167\end{array}$ & $\left.\begin{array}{l}1 \cdot 719 \\
1 \cdot 7185 \\
1 \cdot 720 \\
1 \cdot 7195 \\
1 \cdot 7205 \\
1 \cdot 7195 \\
1 \cdot 719 \\
1 \cdot 719\end{array}\right\}$ & $1.7195 \pm 0.0011$ & $60 \cdot 7 \pm 1 \cdot 1$ \\
\hline Unclassified & & 95 & $1 \cdot 7185$ & 1.7185 & $59 \cdot 7$ \\
\hline
\end{tabular}

Table 2. Significant differences of mean GC content of DNAs of fluorescent pseudomonads

\begin{tabular}{|c|c|c|c|c|c|c|c|c|c|c|}
\hline \multirow[t]{7}{*}{ P. fluorescens biotypes } & $\mathbf{A}$ & $\begin{array}{l}\text { 14.537 } \\
(28)^{*}\end{array}$ & & & & & & & & \\
\hline & B & $\begin{array}{l}14 \cdot 406 \\
(32)^{*}\end{array}$ & $\begin{array}{l}1 \cdot 651 \\
(18) \neq\end{array}$ & & & & & & & \\
\hline & $\mathbf{C}$ & $\begin{array}{l}17 \cdot 690 \\
(32)^{*}\end{array}$ & $\begin{array}{l}0 \cdot 460 \\
(18)\end{array}$ & $\begin{array}{l}1 \cdot 672 \\
(22) \ddagger\end{array}$ & & & & & & \\
\hline & $\mathbf{D}$ & $\begin{array}{l}11 \cdot 593 \\
(40)^{*}\end{array}$ & $\begin{array}{l}7 \cdot 070 \\
(26)^{*}\end{array}$ & $\begin{array}{l}5 \cdot 568 \\
(30)^{*}\end{array}$ & $\begin{array}{l}8 \cdot 369 \\
(30)^{*}\end{array}$ & & & & & \\
\hline & $\mathbf{E}$ & $\begin{array}{c}9.916 \\
(32)^{*}\end{array}$ & $\begin{array}{l}7 \cdot 200 \\
(18)^{*}\end{array}$ & $\begin{array}{l}5 \cdot 432 \\
(22)^{*}\end{array}$ & $\begin{array}{l}8 \cdot 700 \\
(22)^{*}\end{array}$ & $\begin{array}{l}0 \cdot 306 \\
(30)\end{array}$ & & & & \\
\hline & $\mathbf{F}$ & $\begin{array}{l}15 \cdot 824 \\
(26)^{*}\end{array}$ & $\begin{array}{l}2 \cdot 095 \\
(12) \ddagger\end{array}$ & $\begin{array}{l}3 \cdot 719 \\
(16)^{*}\end{array}$ & $\begin{array}{l}3 \cdot 162 \\
(16) \dagger\end{array}$ & $\begin{array}{l}9 \cdot 375 \\
(24)^{*}\end{array}$ & $\begin{array}{r}10 \cdot 330 \\
(16)^{*}\end{array}$ & & & \\
\hline & $\mathbf{G}$ & $\begin{array}{l}\text { 16.912 } \\
(32)^{*}\end{array}$ & $\begin{array}{l}0 \cdot 000 \\
(18)\end{array}$ & $\begin{array}{l}1 \cdot 878 \\
(\mathbf{2 2}) \dagger\end{array}$ & $\begin{array}{l}0 \cdot 439 \\
(22)\end{array}$ & $\begin{array}{l}8.078 \\
(30)^{*}\end{array}$ & $\begin{array}{l}7 \cdot 907 \\
(22)^{*}\end{array}$ & $\begin{array}{l}2 \cdot 238 \\
(16) \dagger\end{array}$ & & \\
\hline \multirow[t]{3}{*}{$P \cdot$ putida biotypes } & $\mathbf{A}$ & $\begin{array}{l}12 \cdot 247 \\
(32) *\end{array}$ & $\begin{array}{l}4 \cdot 841 \\
(18)^{*}\end{array}$ & $\begin{array}{l}3 \cdot 062 \\
(22)^{*}\end{array}$ & $\begin{array}{l}5 \cdot 686 \\
(22)^{*}\end{array}$ & $\begin{array}{l}2 \cdot 450 \\
(30)^{*}\end{array}$ & $\begin{array}{l}2 \cdot 719 \\
(22) \dagger\end{array}$ & $\begin{array}{l}7 \cdot 638 \\
(16)^{*}\end{array}$ & $\begin{array}{l}5 \cdot 352 \\
(22)^{*}\end{array}$ & \\
\hline & B & $\begin{array}{l}17 \cdot 519 \\
(36)^{*}\end{array}$ & $\begin{array}{l}0.531 \\
(22)\end{array}$ & $\begin{array}{l}1 \cdot 377 \\
(26) \ddagger\end{array}$ & $\begin{array}{l}0 \cdot 223 \\
(26)^{*}\end{array}$ & $\begin{array}{l}7 \cdot 787 \\
(34) *\end{array}$ & $\begin{array}{l}7 \cdot 344 \\
(26)^{*}\end{array}$ & $\begin{array}{l}2 \cdot 718 \\
(20) \dagger\end{array}$ & $\begin{array}{l}0 \cdot 609 \\
(26)\end{array}$ & $\begin{array}{l}4 \cdot 801 \\
(26)^{*}\end{array}$ \\
\hline & & & $\mathbf{A}$ & B & $\mathrm{C}$ & $\mathbf{D}$ & $\mathbf{E}$ & $\mathbf{F}$ & $\mathbf{G}$ & A \\
\hline
\end{tabular}

Number of degrees of freedom are given in parentheses for values of $t$ calculated by the method of Fisher (1925). Pairs significantly different at the $99 \%$ confidence level are marked *, at the $95 \%$ level $\dagger$, at the $80 \%$ confidence level $\ddagger$. Pairs not marked are not significantly different.

have pointed out that biotype $\mathbf{B}$ is more fuorescens-like than is biotype $\mathbf{A}$. Indeed this resemblance extends to the GC contents and biotype $\mathbf{B}$ of $\boldsymbol{P}$. putida is indistinguishable from $\boldsymbol{P}$. fluorescens biotypes A, B and $\mathbf{G}$ on this basis. Biotype $\mathbf{A}$ of $\boldsymbol{P}$. putida, on the other hand, has DNA more nearly like $\boldsymbol{P}$. fluorescens biotypes $\mathrm{E}$ and 
D, but significantly different from both at the $95 \%$ confidence level. $P$. putida biotype $\mathbf{B}$ thus probably warrants designation as a species. In concert with my Californian colleagues, I also would refrain from such designation until comparisons can be made with the various named plant pathogens or authentic surviving holotypes of the named species which have been reduced to synonomy with $P$. putida.

Table 2 is a display of the statistical tests for significant differences in the mean GC content representative of each set of fluorescent pseudomonads. The data concerning the GC content of the representatives of Pseudomonas fuorescens biotypes A, B, C and G clearly demonstrate no highly significant differences in the overall composition of the genetic material. While biotype $\mathrm{F}$ appears to be the lowest in GC content of all the fluorescent pseudomonads, too few determinations have been made to separate this biotype from biotype $\mathbf{A}$ with any high degree of confidence. Biotypes $\mathrm{D}$ and $\mathrm{E}$, on the other hand, are distinctly different in GC content from the remainder of the $\boldsymbol{P}$. fluorescens group. On the basis of this difference and the phenotypic differences set forth by Stanier et al. (1966) a specific epithet for $\boldsymbol{P}$. chlororaphis and $\boldsymbol{P}$. aureofaciens appeais to be justifiable and one must reject the proposal that these species be reduced to synonymy with $\boldsymbol{P}$. fluorescens. The difference in GC content of as much as $3 \%$ between $\boldsymbol{P}$. fluorescens and these phenazine-

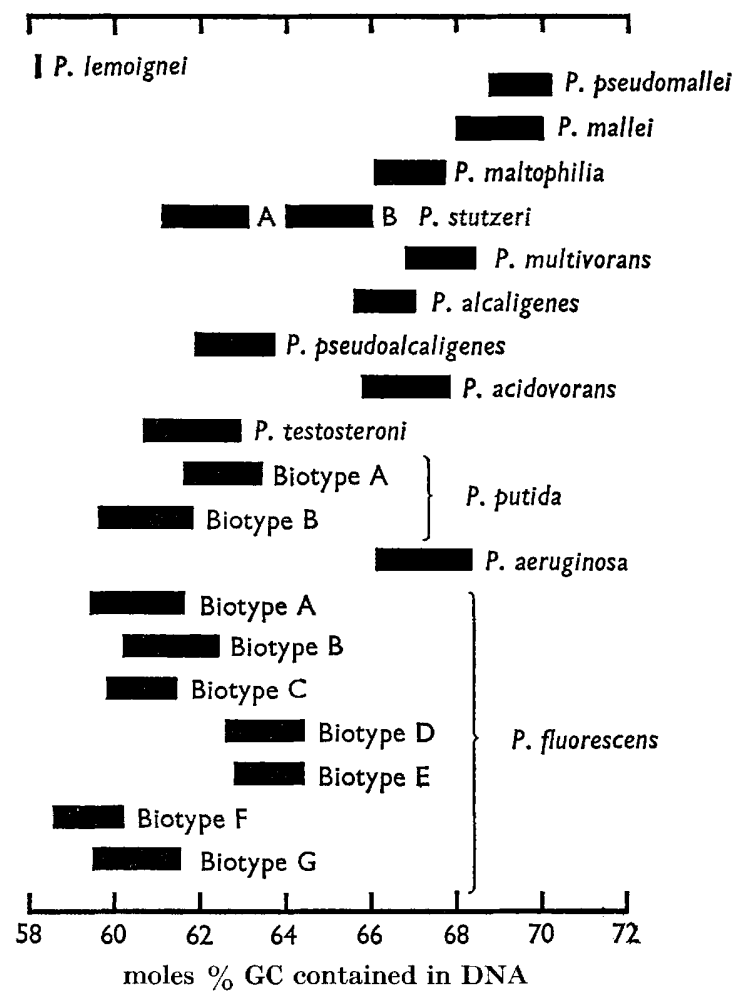

Fig. 1. The GC content of DNAs of the aerobic pseudomonads. Values plotted are means \pm one standard deviation. Species and biotypes represent those studied by Stanier et al. (1966), the pseudomallei group of Redfearn et al. (1966) and the monotypic Pseudomonas lemoignei of Delafield et al. (1965). 
producing organisms sets them apart, but does not preclude the existence of substantial genetic information shared in common. Again, the high degree of phenotypic similarity and of GC content of $\boldsymbol{P}$. chlororaphis and $\boldsymbol{P}$. aureofaciens indicates the advisability of reducing the latter to synonymy with the former. Quite striking is the difference observed when all these fluorescent pseudomonads are contrasted with $\boldsymbol{P}$. aeruginosa. The DNA of the latter species has GC $67 \cdot 2 \%$, distinctly separate from the GC content of all other fluorescent pseudomonads. Obviously, the conclusion of Lysenko (1961) that $\boldsymbol{P}$. chlororaphis and $\boldsymbol{P}$. aureofaciens are closely allied to $\boldsymbol{P}$. aeruginosa is not substantiated. This solitary position of $\boldsymbol{P}$. aeruginosa is indeed unfortunate, for this is the sole pseudomonad in which a system for genetic recombination is known (Holloway, 1955; Holloway \& Monk, 1959), and if experience with the Enterobacteriaceae, Bacillaceae and Neisseria are any guide, interspecific hybridizations of $\boldsymbol{P}$. aeruginos $a$ with other fluorescent pseudomonads are of slight likelihood (see Marmur et al. $1963 a$ ).

Fig. 1 provides a summary of the mean GC contents of the representatives of the fluorescent pseudomonads in comparison with the aerobic pseudomonads described below.

\section{The acidovorans group}

The 26 strains placed in the acidovorans group by Stanier et al. (1966) have all been examined for GC content of their DNA with results as listed in Table 3 . Fifteen of the strains are readily separable into a set possessing 66.8 moles \% GC and another 9 strains can be assigned to a set possessing $61 \cdot 8 \% \mathrm{GC}$. This division of the cultures into the two species Pseudomonas acidovorans and $\boldsymbol{P}$. testosteroni is further correlated with the nutritional differences established by Stanier et al. (1966). Two strains $(60,298)$ which bear phenotypic resemblances to the acidovorans group differ sufficiently from each other and from each of the named species in GC content and in nutritional properties to preclude their identification with either of the two species of the acidovorans group. It is possible that these represent additional species which have not otherwise been encountered in the study of Stanier et al. (1966).

Stanier et al. (1966) point out the discrepancy between the growth of strains 61 and 62, which they received as Comamonas terrigena but have identified as typical representatives of Pseudomonas acidovorans, and of ATCC 8461, the type culture of $C$. terrigena. The DNA of the latter culture and of its peritrichate mutant have been examined by Leifson \& Mandel (1966). By using identical techniques and reference standards, they find the type culture to contain DNA of $64 \% \mathrm{GC}$, or $2-3 \%$ poorer in GC than the DNA of strains 61 and 62 . Regardless of what taxonomic lodging Comamonas terrigena may eventually find, the epithet terrigena cannot be used as an earlier synonym for $P$. acidovorans.

\section{The alcaligenes group}

The DNAs of all 7 strains included in this group by Stanier et al. (1966) were analysed; Table 4 gives these data. There was no significant difference between the density determinations of the DNAs of 6 strains assigned to Pseudomonas pseudoalcaligenes, but the representative of $\boldsymbol{P}$. alcaligenes was significantly richer in GC content by $3.5 \%$; this difference is significant at the $99.9 \%$ probability level. 
When the GC contents of the representatives of the alcaligenes group are contrasted with those of the acidovorans group, Pseudomonas alcaligenes DNA does not differ significantly from that of $\boldsymbol{P}$. acidovorans. The $1 \%$ difference in GC content

\section{Table 3. Buoyant density and GC content of DNAs of representatives of the acidovorans group}

Values given for mean density are rounded averages of at least two determinations of the buoyant density in $\mathrm{CsCl}$ at 44,770 and 42,040 rev./min. Strain numbers correspond to designations of Stanier et al. (1966).

\begin{tabular}{|c|c|c|c|c|}
\hline \multirow[b]{2}{*}{ Species } & \multirow[b]{2}{*}{ Strain } & \multirow{2}{*}{$\begin{array}{l}\text { Mean density } \\
\left.\text { (g. } / \mathrm{cm}^{3}\right)^{2}\end{array}$} & \multicolumn{2}{|c|}{$\begin{array}{l}\text { Mean value and stanaara deviation } \\
\text { calculated for each group }\end{array}$} \\
\hline & & & Density (g./cm..$^{3}$ ) & GC (moles \%) \\
\hline P. acidovorans & $\begin{array}{r}14 \\
24 \\
29 \\
61 \\
62 \\
80 \\
102 \\
103 \\
105 \\
106 \\
114 \\
125 \\
129 \\
146 \\
148\end{array}$ & $\left.\begin{array}{l}1 \cdot 7255 \\
1 \cdot 7255 \\
1 \cdot 7255 \\
1 \cdot 726 \\
1 \cdot 725 \\
1 \cdot 725 \\
1 \cdot 726 \\
1 \cdot 726 \\
1 \cdot 725 \\
1 \cdot 726 \\
1 \cdot 727 \\
1 \cdot 725 \\
1 \cdot 7255 \\
1 \cdot 7245 \\
1 \cdot 7255\end{array}\right\}$ & $1 \cdot 7255 \pm 0 \cdot 0010$ & $66 \cdot 8 \pm 1 \cdot 0$ \\
\hline P. testosteroni & $\begin{array}{r}15 \\
16 \\
25 \\
27 \\
28 \\
78 \\
79 \\
138 \\
139\end{array}$ & $\left.\begin{array}{l}1 \cdot 7205 \\
1 \cdot 721 \\
1 \cdot 720 \\
1 \cdot 7205 \\
1 \cdot 721 \\
1 \cdot 720 \\
1 \cdot 720 \\
1 \cdot 721 \\
1 \cdot 7215\end{array}\right\}$ & $1 \cdot 7206 \pm 0.0011$ & $61 \cdot 8 \pm 1 \cdot 1$ \\
\hline Unclassified & $\begin{array}{r}60 \\
298\end{array}$ & $\begin{array}{l}1 \cdot 7175 \\
1 \cdot 723\end{array}$ & $\begin{array}{l}1 \cdot 7175 \\
1 \cdot 723\end{array}$ & $\begin{array}{l}58 \cdot 7 \\
64 \cdot 3\end{array}$ \\
\hline
\end{tabular}

Table 4. Buoyant density and GC content of DNAs of representatives of the alcaligenes group

Values given for mean density are rounded averages of at least two determinations of the buoyant density in $\mathrm{CsCl}$ at 44,770 and 42,040 rev./min. Strain numbers correspond to designations of Stanier et al. (1966).

\begin{tabular}{|c|c|c|c|c|}
\hline \multirow[b]{2}{*}{ Species } & \multirow[b]{2}{*}{ Strain } & \multirow[b]{2}{*}{$\begin{array}{l}\text { Mean density } \\
\left(\text { g. } / \mathrm{cm}^{3}{ }^{3}\right)\end{array}$} & \multicolumn{2}{|c|}{$\begin{array}{l}\text { Mean value and standard deviation } \\
\text { calculated for each group }\end{array}$} \\
\hline & & & Density (g./cm. $\left.{ }^{3}\right)$ & GC (moles \%) \\
\hline P. alcaligenes & 142 & $1 \cdot 725$ & $1.7250 \pm 0.0007$ & $66 \cdot 3 \pm 0 \cdot 7$ \\
\hline P. pseudoalcaligenes & $\begin{array}{r}63 \\
65 \\
66 \\
297 \\
299 \\
417\end{array}$ & $\left.\begin{array}{l}1 \cdot 721 \\
1 \cdot 721 \\
1 \cdot 722 \\
1 \cdot 7225 \\
1 \cdot 721 \\
1 \cdot 722\end{array}\right\}$ & $1 \cdot 7216 \pm 0 \cdot 0009$ & $62 \cdot 8 \pm 0.9$ \\
\hline
\end{tabular}


between $\boldsymbol{P}$. pseudoalcaligenes and $\boldsymbol{P}$. testosteroni is significant at the $95 \%$ confidence level. Hence the GC content can aid in distinguishing these species, even when used only in conjunction with conventional bacteriological diagnostic tests. Neither unclassified member of the acidovorans group has GC contents which match either species of the alcaligenes group.

\section{Pseudomonas multivorans}

Of the 19 strains studied by Stanier et al. (1966), 12 were analysed for GC content. The data in Table 5 show that the groups of strains examined are quite alike in GC content and the defective strains $(385,396,397,399)$ did not display any difference in this regard.

Table 5. Buoyant density and GC content of DNAs of representative strains of Pseudomonas multivorans

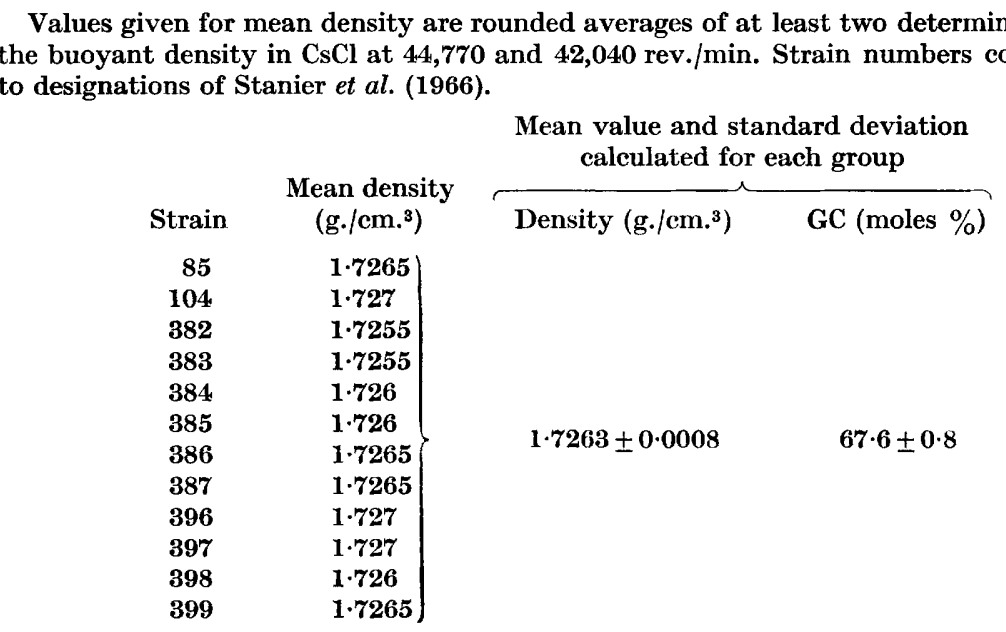

There seems little chance that Pseudomonas multivorans could be mistaken for $\boldsymbol{P}$. aeruginosa, P. maltophilia, P. acidovorans, $P$. mallei or $P$. pseudomallei on cultural and physiological comparison. These high GC representatives all differ in base composition from $\boldsymbol{P}$. multivorans by relatively small amounts, the smallest difference being found with $\boldsymbol{P}$. aeruginosa. The $t$-test indicates a significant difference at $85 \%$ probability; the other species cited above have differences calculated to be of significance at the $95 \%$ probability level or better.

\section{Pseudomonas stutzeri}

The 17 strains studied by Stanier et al. (1966) were analysed for GC content, with the results shown in Table 6 . Two clearly differentiated groups are revealed by this analysis. Group B contains the neotypes proposed by van Niel \& Allen (1952) and by Stanier et al. (1966); hence, $P$. stutzeri is characterized by DNA of $65 \%$ GC content. Group A differs in having DNA of $62 \cdot 1 \%$ GC and the disparity is significant at the $99.9 \%$ confidence level. If these bacteria have genomes containing as few as $10^{7}$ nucleotide pairs in their DNA, then this difference represents approxi- 
mately $2.9 \times 10^{4} \mathrm{GC}$ substitutions for adenine + thymine (A'T) pairs in the DNA of organisms of group B as contrasted with group A organisms. If these base-pair substitutions are spread at random, we should predict little or no genetic material in common. Stanier et al. (1966) were reluctant to propose the designation of a new

\section{Table 6. Buoyant density and GC content of DNAs of Pseudomonas stutzeri and $P$. stanieri sp.nov.}

\begin{tabular}{|c|c|c|c|c|}
\hline \multirow[b]{2}{*}{ Group } & \multirow[b]{2}{*}{ Strain } & \multirow{2}{*}{$\begin{array}{l}\text { Mean density } \\
\quad\left(\mathrm{g} \cdot / \mathrm{cm} \cdot{ }^{3}\right)\end{array}$} & \multicolumn{2}{|c|}{$\begin{array}{l}\text { Mean value and standard deviation } \\
\text { calculated for each group }\end{array}$} \\
\hline & & & Density (g./cm. ${ }^{\mathbf{3}}$ ) & GC (moles \%) \\
\hline A (P. stanieri sp.nov.) & $\begin{array}{l}220 \\
223 \\
224 \\
225 \\
228 \\
320\end{array}$ & $\left.\begin{array}{l}1 \cdot 721 \\
1 \cdot 7195 \\
1 \cdot 721 \\
1 \cdot 7215 \\
1 \cdot 7215 \\
1 \cdot 721\end{array}\right\}$ & $1 \cdot 7209 \pm 0 \cdot 0010$ & $62 \cdot 1 \pm 1 \cdot 0$ \\
\hline B (P. stutzeri) & $\begin{array}{l}221 \\
222 \\
226 \\
227 \\
229 \\
275 \\
316 \\
318 \\
319 \\
321 \\
419\end{array}$ & $\left.\begin{array}{l}1 \cdot 724 \\
1 \cdot 7235 \\
1 \cdot 7235 \\
1 \cdot 7243 \\
1 \cdot 724 \\
1 \cdot 723 \\
1 \cdot 7245 \\
1 \cdot 724 \\
1 \cdot 724 \\
1 \cdot 724 \\
1 \cdot 724\end{array}\right\}$ & $1 \cdot 7237 \pm 0.0010$ & $65 \cdot 0 \pm 1 \cdot 0$ \\
\hline
\end{tabular}

species for organisms of group A. Such a separate designation is felt to be necessary by the present author, despite the lack of as clear a set of phenotypic traits correlated with this different base composition of the DNA as was observed in the acidovorans group. The variety of phenotypic traits displayed in the group of cultures studied as $\boldsymbol{P}$. stutzeri would seem to make it quite difficult to demonstrate such a correlation using the data at hand. Sebald \& Véron (1963) have already established a precedent for altering nomenclatural designations based upon determinations of DNA base composition, and Campbell \& Postgate (1965) have provided descriptions of the species of Desulfotomacculum in which the GC content of the described species are definitive, along with one or two other distinguishing phenotypic traits. For these reasons I propose that the organisms of group A be separated from the species $P$. stutzeri and given a specific designation.

A review of the nomenclatural status of Bacillus denitrificans II Burri and Stutzer by van Niel \& Allan (1952) elucidated the unwarranted confusion attending the classification of this organism and the proper recognition of Pseudomonas stutzeri (Lehmann and Newmann) Kluyver as the combined epithets. Further confusion would result if one of the specific synonyms for $\boldsymbol{P}$. stutzer $i$ were now used to describe the species of low GC content, particularly when neither holotypes nor neotypes of the cultures which have borne the synonyms appear to exist for which the base composition can be determined. It is therefore proposed that the new species be 
named after Professor R. Y. Stanier in recognition of his contributions to the knowledge of the physiology and taxonomy of the genus Pseudomonas. A description follows, based in the main on the data of Stanier et al. (1966).

Pseudomonas stanieri sp.nov., description as for $\boldsymbol{P}$. stutzeri conforming in all respects to the ideal phenotype of Stanier et al. (1966). DNA contains $62 \cdot 1$ moles $\%$ GC. Differentiated from most strains of $\boldsymbol{P}$. stutzeri by the ability to utilize ethanolamine and mannitol and the inability to utilize propionate. No growth at $43^{\circ}$. Strains 224 and 225 conform strictly to this description and strain 224 (strain AB 212 of Dr H. Lautrop, Statens Seruminstitut, Copenhagen; A'TCC 17591) is proposed as the holotype.

Strains 223, 320 and 228 are atypical in many nutritional characters. It is possible that these strains may not be $\boldsymbol{P}$. stanieri, but it would be premature to consider the creation of still another species.

Two strains $(226,227)$ of Pseudomonas stutzeri have yielded DNA specimens which display a departure from the Gaussian distribution of DNA molecules in the CsCl gradient found with all other specimens reported in this study (as well as for over 1200 other samples of DNAs of bacterial origin examined in the author's laboratory in the past years). Figure 2 shows the appearance of a microdensitometer tracing of the DNA of strain 227. A DNA satellite is evident on the less dense side of the main DNA band. There was no difference in the position and amount of the satellite band in DNA extracted from 226. To ensure that the satellite was indeed composed of DNA, samples were diluted with water to $1 \%$ the salt concentration, boiled for $10 \mathrm{~min}$. and chilled in ice. This denaturation was accomplished at low concentrations of DNA (5-10 $\mu \mathrm{g} . / \mathrm{ml}$.) to guard against aggregation phenomena (Marmur, Rownd \& Schildkraut, 1963). Upon examination of the CsCl gradient, with DNA of Escherichia coli as a reference standard, both satellite and main DNA bands were found to be increased in density by $0.014-0.015 \mathrm{~g} . / \mathrm{cm} .^{3}$ and the bands were increased in distribution width as would be expected if both represented double-stranded DNA. Subcultures of both strains were re-examined by Dr N. J. Palleroni and not found to be contaminated nor to be different from the previous description. The cultures were streaked on nutrient agar and single colonies again streaked. Six clones of each strain were then cultivated in nutrient broth, and the DNAs isolated and purified by the method of Marmur (1961). Again each specimen contained the same satellite and in the same proportion as in the original observations, irrespective of the fact that one sample of each strain was cultivated at $37^{\circ}$ rather than $30^{\circ}$ as had been the remainder. The satellite DNA represents $10-15 \%$ of the total DNA, as estimated from the area under the curve of the ultraviolet-absorbing material. If the satellite DNA corresponded to the presence of a bacterial contaminant in each culture, the contaminant would have to make up approximately that proportion of the population. Since microscopic examination of the suspended cultures did not reveal any tendency for the organisms to aggregate in groups, it is safe to dismiss contamination as the source of the satellite DNA. The satellite DNA is remarkably like that reported to be present in species of Halobacterium (Joshi, Guild \& Handler, 1963). The latter authors concluded that an episomal element was probably present. Preliminary experiments by Mandel \& Goldschmidt (unpublished) would indicate that it is likely that some form of cytoplasmic DNA (plasmid or episome) is present. Growth of strains 226 and 227 in nutrient broth containing neutral acriflavine $25 \mu \mathrm{g} . / \mathrm{ml}$. 


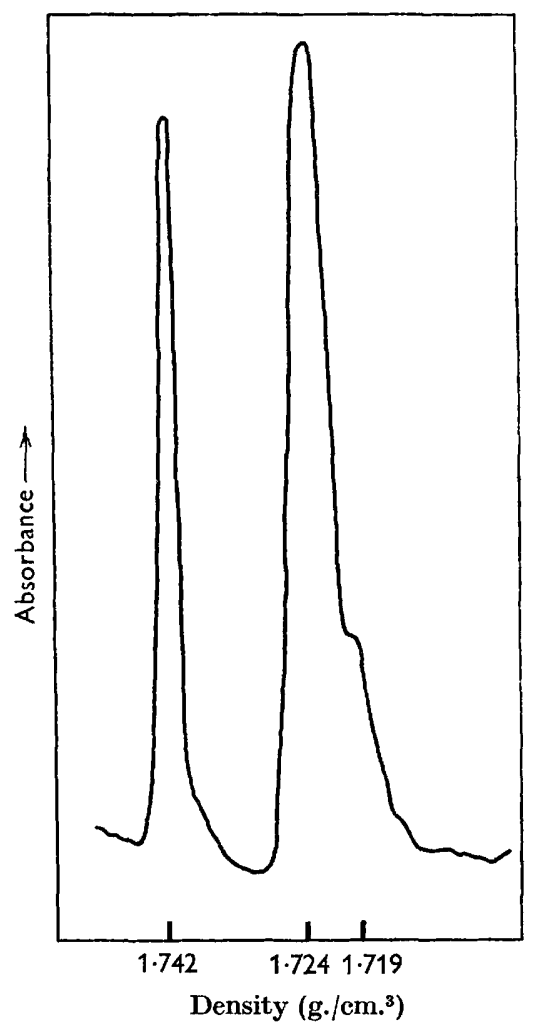

Fig. 2. Microdensitometer tracing of the ultraviolet absorbing bands of purified DNA of Pseudomonas stutzeri strain 227. Film exposed after $22 \mathrm{hr}$ at $44,770 \mathrm{rev}$./min. in $5 \cdot 7 \mathrm{M}-\mathrm{CsCl}$ at $25 \cdot 0^{\circ}$. The band at the left is that of the reference DNA (0.5 $\mu \mathrm{g}$.) of SP 8 bacteriophage.

(Hirota \& Iijima, 1957) has yielded populations where the satellite DNA is either absent or so decreased in amount as not to be discernible on the ultraviolet photographs of the extracted DNA at equilibrium in the $\mathrm{CsCl}$ gradient. Single colonies of strain 227 lacking the satellite are now being studied in the laboratory of Professor Stanier for alteration of phenotypic traits and in this laboratory for the ability to re-acquire the trait by transmission from the wild-type strains. It is of interest that in the data of Stanier et al. (1966) strains 226 and 227 deviate from the remainder of their $\boldsymbol{P}$. stutzeri strains in eight common features, five of which are positive characters.

\section{Pseudomonas maltophilia}

This species is represented by 4 strains analysed of the 23 studied by Stanier $e$ al. (1966). The indicated GC content was 66.9 moles $\%$ and all 4 strains were quite uniform in this respect (Table 7). The sample is too small to guarantee that there is no other GC type present, but the uniformity of phenotypic characters present in the 23 strains does not raise any such suspicion. 
Table 7. Buoyant density and GC content of DNA of representative strains of Pseudomonas maltophilia

Values given for mean density are rounded averages of at least two determinations of the buoyant density in $\mathrm{CsCl}$ at 44,770 and 42,040 rev./min. Strain numbers correspond to designations of Stanier et al. (1966).

\begin{tabular}{|c|c|c|c|}
\hline \multirow[b]{2}{*}{ Strain } & \multirow{2}{*}{$\begin{array}{l}\text { Mean density } \\
\quad\left(\mathrm{g} . / \mathrm{cm} .^{3}\right)\end{array}$} & \multicolumn{2}{|c|}{$\begin{array}{l}\text { Mean value and standard deviation } \\
\text { calculated for the group }\end{array}$} \\
\hline & & Density (g./cm. ${ }^{3}$ ) & GC (moles \%) \\
\hline 67 & $1 \cdot 726$ & & \\
\hline $\begin{array}{r}72 \\
301\end{array}$ & $\begin{array}{l}1 \cdot 7255 \\
1 \cdot 7255\end{array}$ & $1 \cdot 7256 \pm 0 \cdot 0008$ & $66 \cdot 9 \pm 0 \cdot 8$ \\
\hline 303 & $1 \cdot 7255$ & & \\
\hline
\end{tabular}

The pseudomallei-mallei group

Table 8 lists the buoyant densities of the DNA of 6 of the 26 strains of Pseudomonas pseudomallei and $\boldsymbol{7}$ of the 15 strains of $P$. mallei studied by Redfearn et al. (1966). These bacteria had DNA of the highest GC content found in the pseudomonads. The difference in GC content for the two groups is not of high significance (80\% probability).

Table 8. Buoyant density and GC content of DNAs of representatives of pseudomallei group

Values given for mean density are rounded averages of at least two determinations of the buoyant density in $\mathrm{CsCl}$ at 44,770 and 42,040 rev./min. Strain numbers correspond to designations of Redfearn et al. (1966).

\begin{tabular}{|c|c|c|c|c|}
\hline \multirow[b]{2}{*}{ Species } & \multirow[b]{2}{*}{ Strain } & \multirow{2}{*}{$\begin{array}{l}\text { Mean density } \\
\quad\left(\mathrm{g} \cdot / \mathrm{cm} .^{3}\right)\end{array}$} & \multicolumn{2}{|c|}{$\begin{array}{l}\text { Mean value and standard deviation } \\
\text { calculated for each group }\end{array}$} \\
\hline & & & Density (g. $\left./ \mathrm{cm}^{3}{ }^{3}\right)$ & GC (moles \%) \\
\hline$P \cdot$ pseudomallei & $\begin{array}{l}\text { NBL } 111 \\
\text { NBL } 113 \\
\text { NBL } 114 \\
\text { NBL } 117 \\
\text { NBL } 121 \\
\text { NBL } 123\end{array}$ & $\left.\begin{array}{l}1 \cdot 728 \\
1 \cdot 728 \\
1 \cdot 728 \\
1 \cdot 728 \\
1 \cdot 7285 \\
1 \cdot 728\end{array}\right\}$ & $1 \cdot 7281 \pm 0 \cdot 0007$ & $69 \cdot 5 \pm 0 \cdot 7$ \\
\hline P. mallei & $\begin{array}{l}\text { NBL } 1 \\
\text { NBL } 2 \\
\text { NBL 4 } \\
\text { NBL } 7 \\
\text { NBL 16 } \\
\text { NBL } 17 \\
\text { NBL } 19\end{array}$ & $\left.\begin{array}{l}1 \cdot 728 \\
1 \cdot 728 \\
1 \cdot 727 \\
1 \cdot 7265 \\
1 \cdot 7275 \\
1 \cdot 7278 \\
1 \cdot 7275\end{array}\right\}$ & $1 \cdot 7276 \pm 0.0010$ & $69 \cdot 0 \pm 1 \cdot 0$ \\
\hline
\end{tabular}

Pseudomonas lemoignei sp.nov.

Delafield et al. (1965) have described a new species of aerobic pseudomonad which has been distinguished from the bulk of the pseudomonads by the criteria used by R. Y. Stanier and his collaborators. The holotype and sole strain of this poly- $\beta$ hydroxybutrate-digesting strain has DNA of $58.2 \%$ GC (Table 9 ). It therefore represents the lowest GC content found among the aerobic pseudomonads reported above. 
Table 9. Buoyant density and mean GC content of the DNA of additional cultures received as species of Pseudomonas

\begin{tabular}{|c|c|c|c|}
\hline Organism & Strain designation and source & $\begin{array}{l}\text { Density } \\
\left.\text { (g./cm. }{ }^{3}\right)\end{array}$ & $\begin{array}{c}\text { GC } \\
(\text { moles } \%)\end{array}$ \\
\hline$P$. lemoignei sp.nov. & $\begin{array}{l}\text { Strain } 443 \text { of Delafield et al. }(1965) \text {; } \\
\text { received as harvest of organisms } \\
\text { from Dr N. J. Palleroni, } \\
\text { University of California, Berkeley }\end{array}$ & $1 \cdot 717$ & $58 \cdot 2$ \\
\hline \multirow[t]{2}{*}{$P$. pseudoalcaligenes } & $\begin{array}{l}\text { Strain } 63 \mathrm{AD} \text { of Dr M. Véron, } \\
\text { Institut Pasteur; received from } \\
\text { Prof. R. Y. Stanier as } 440\end{array}$ & 1.721 & $62 \cdot 2$ \\
\hline & $\begin{array}{l}\text { Strain } 63 \text { AS of Dr M. Véron; } \\
\text { received from Prof. R. Y. } \\
\text { Stanier as } 441\end{array}$ & $1 \cdot 722$ & $63 \cdot 2$ \\
\hline \multirow[t]{4}{*}{$P$. aeruginosa } & AтcC 8707 & $1 \cdot 726$ & $67 \cdot 3$ \\
\hline & ATCC 8689 & $1 \cdot 726$ & $67 \cdot 3$ \\
\hline & $\begin{array}{l}\text { ICPPB } 2020 ; \text { received from Dr M. P. } \\
\text { Starr, University of California, } \\
\text { Davis }\end{array}$ & $1 \cdot 7257$ & $67 \cdot 0$ \\
\hline & $\begin{array}{l}\text { NRRL B 23; studied as strain } 54 \\
\text { by Stanier } \text { et al. (1966); received } \\
\text { from Dr J. Marmur, Albert } \\
\text { Einstein Medical College, New } \\
\text { York }\end{array}$ & 1.727 & $68 \cdot 4$ \\
\hline$P \cdot$ polycolor & $\begin{array}{l}\text { PP2; received from Dr M. P. Starr, } \\
\text { University of California, Davis }\end{array}$ & $1 \cdot 726$ & $67 \cdot 3$ \\
\hline P. aminovorans & $\begin{array}{l}\text { Strain } 26 \text { of den Dooren de Jong } \\
(\mathbf{1 9 2 6 )} \text {; received from Dr E. R. } \\
\text { Leadbetter, Amherst College, } \\
\text { Amherst }\end{array}$ & 1.722 & $63 \cdot 2$ \\
\hline \multirow[t]{2}{*}{ P. schuylkilliensis } & $\begin{array}{l}\text { NRRL B 1104; from Dr W. C. } \\
\text { Haynes, U.S. Department of Agricul- } \\
\text { ture, Peoria, Ill. }\end{array}$ & $1 \cdot 7195$ & $60 \cdot 7$ \\
\hline & $\begin{array}{l}\text { NRRL B 1105; from Dr W. C. } \\
\text { Haynes }\end{array}$ & $1 \cdot 7197$ & $60 \cdot 9$ \\
\hline \multirow[t]{3}{*}{ P. geniculata } & $\begin{array}{l}\text { NRRL B 1603; from Dr W. C. } \\
\text { Haynes }\end{array}$ & $1 \cdot 719$ & $60 \cdot 2$ \\
\hline & $\begin{array}{l}\text { NRRL B 2080; from Dr W. C. } \\
\text { Haynes }\end{array}$ & $1 \cdot 725$ & $66 \cdot 3$ \\
\hline & $\begin{array}{l}\text { NRRL B 2337; from Dr W. C. } \\
\text { Haynes }\end{array}$ & $1 \cdot 726$ & $67 \cdot 3$ \\
\hline P. atlantica & $\begin{array}{l}\text { NCMB } 301 \text { Received from Dr J. M. } \\
\text { Shewan, Torry Research Station, } \\
\text { Aberdeen }\end{array}$ & $1 \cdot 7025$ & $43 \cdot 5$ \\
\hline P. mallei & $\begin{array}{l}\text { NCTC 3709; received from Mr Paul } \\
\text { Baumann, University of California, } \\
\text { Berkeley }\end{array}$ & $1 \cdot 728$ & $69 \cdot 4$ \\
\hline P. tabaci & $\begin{array}{l}\text { PT 1; received from Dr M. P. Starr, } \\
\text { pathogenic for tobacco }\end{array}$ & $1 \cdot 717$ & $58 \cdot 2$ \\
\hline P. phaseolicola & $\begin{array}{l}\text { PM 142; received from Dr M. P. } \\
\text { Starr, pathogenic for beans }\end{array}$ & $1 \cdot 7177$ & $58 \cdot 9$ \\
\hline P. methanica & $\begin{array}{l}\text { Harvested organisms received from } \\
\text { Dr J. W. Foster, The University } \\
\text { of Texas, Austin }\end{array}$ & 1.711 & $52 \cdot 1$ \\
\hline P. xanthe & $\begin{array}{l}\text { F 3.0; received from Dr O. B. } \\
\text { Weeks, New Mexico State } \\
\text { University, University Park }\end{array}$ & $1 \cdot 7285$ & $69 \cdot 9$ \\
\hline
\end{tabular}




\section{Other aerobic pseudomonads}

Table 9 lists a number of additional cultures which were analysed for the GC content of their DNAs. Two other strains of Pseudomonas pseudoalcaligenes have been identified as such by Drs Stanier, Palleroni and Doudoroff; their GC contents fall within the range established for the cultures previously described.

Four additional cultures of Pseudomonas aeruginosa were analysed. The first two listed under this name in Table 9 had originally been erroneously described as $\boldsymbol{P}$. fluorescens, as noted in the catalogue of the American Type Culture Collection (1964). All four strains have DNA of GC content characteristic for $\boldsymbol{P}$. aeruginosa. The representative of $\boldsymbol{P}$. polycolor had DNA of a GC content like that of $\boldsymbol{P}$. aeruginosa, adding weight to the proposal of Elrod \& Braun (1942) that this plant pathogen is identical with $\boldsymbol{P}$. aeruginosa, despite some differences in cultural characteristics. Dr T. Feary (unpublished results) has examined the sensitivity of this culture to aeruginosa phages and found it to be attacked by more virulent and temperate phages than any other strain of $\boldsymbol{P}$. aeruginosa.

The holotype of Pseudomonas aminovorans (den Dooren de Jong, 1926) has 63.2 moles \% GC. It cannot be placed with any certainty into any of the species delineated by Stanier et al. (1966).

Two additional strains of Pseudomonas schuylkilliensis have GC contents not significantly different from the $\boldsymbol{P}$. fluorescens biotype $\mathrm{G}$, in which group Stanier et al. (1966) placed strain 267 (NRRL в 9). The latter culture was also identified as $\boldsymbol{P}$. fluorescens by Dr W. C. Haynes, who provided these cultures. The epithet should be reduced to synonymy with $\boldsymbol{P}$. fluorescens.

Strains of Pseudomonas geniculata pose another problem. The description of this species is that of a fluorescent pseudomonad isolated from the Schuylkill River in Pennsylvania. Strains 269 (NRRL B 1606) and 271 (NRRL в 1612) were studied by Stanier et al. (1966) and placed in $\boldsymbol{P}$. fluorescens biotype B; each has DNA of $60 \%$ GC content. There are an additional 3 strains received as $\boldsymbol{P}$. geniculata in Table 9 . One of these (NRRL в 1603) has DNA of $60 \%$ GC composition while the other two have 66 or $67 \%$ GC. De Ley \& Van Muylem (1963) reported the GC content of $\boldsymbol{P}$. geniculata 338 to be $67 \cdot 7 \%$. Their culture was obtained from Lysenko, who proposed it as the neotype for the species (Lysenko, 1961). His description of the organism is that of a non-fluorescent pseudomonad of little enzymic capacity.

Strains NRRL B 2080 and B 2337 , with $66-68 \%$ GC have recently been identified by Dr Palleroni as $P$. multophilia. The same is probably true for the organisms studied by De Ley \& van Muylem (1963).

The strain of Pseudomonas atlantica analysed is shown in Table 9 to have DNA of 43.5 moles \% GC. The source of this culture is ostensibly the same as that organism analysed by De Ley \& Friedman (1965) and found by them to have DNA of $66.4 \%$ GC. The culture examined in this laboratory was obtained directly from Dr J. M. Shewan (National Collection of Industrial Bacteria, Torry Research Station, Aberdeen, Scotland), while De Ley \& Friedman received their specimen from Dr O. Lysenko, who reported having received it from Dr Shewan. The report of Lysenko (1961) noted that his culture differed in some characters from the original description. Another specimen of an agar-utilizing and alginate-utilizing Gramnegative rod labelled $\boldsymbol{P}$. atlantica was found to have DNA of $55 \% \mathrm{GC}$ content 
(Colwell \& Mandel, 1964b). In view of this confusion it is impossible to state what the GC content of $\boldsymbol{P}$. atlantica is and whether it shows any affinity with the genus Pseudomonas as defined by Stanier et al. (1966).

Table 9 also lists one further specimen of Pseudomonas mallei. The GC content of the DNA matches the composition found for the strains provided by Redfearn $e t$ al. (1966; Table 8).

Data for two phytopathogenic fluorescent pseudomonads, Pseudomonas tabaci and $P$. phaseolicola, are given in Table 9. Both have DNA of 58 to 59 moles $\%$ GC content, at the low GC extreme of the fluorescent group. Whether these, and other similar fluorescent phytopathogenic pseudomonads, can be accommodated within one of the established biotypes of $\boldsymbol{P}$. fluorescens must await full examination of the nutritional and enzymic properties of this economically important group of bacteria.

Dworkin \& Foster (1956) recommended that Methanomonas methanica be transferred to the genus Pseudomonas. The GC content of the authentic culture provided by $\mathrm{Dr}$ J. W. Foster is $\mathbf{5 2}$ moles \% (Table 9) and would thereby be remote in base composition from those organisms which Stanier et al. (1966) and the present author would include in the genus Pseudomonas. The representatives of Hydrogenomonas (which are to be reported on elsewhere by Doudoroff and collaborators and by myself) have DNA base compositions in the range reported for Pseudomonas. The proper generic classification of the methane-oxidizing pseudomonad is obscure.

The last culture listed in Table 9, Pseudomonas xanthe, exemplifies another problem in the classification of bacteria. The culture is apparently Gram-negative on routine examination but does not lyse when treated with high concentrations of sodium lauryl sulphate (up to $10 \%, \mathrm{w} / \mathrm{v}$ ). In the author's experience, all Gramnegative bacteria (and a few Gram-positive organisms) lyse promptly upon addition of this detergent. Dr O. B. Weeks has advised me that this strain, as well as others bearing the same name, gives an equivocal Gram reaction by the Hucker method but is definitely Gram positive when stained by Kopeloff's procedure. Zettnow's original culture apparently is not available for comparison.

\section{DISCUSSION}

Stanier et al. (1966) have proposed a rigorous definition for the genus Pseudomonas based upon morphological and physiological properties. The inclusion of a range of DNA base compositions was deferred. The arguments for setting such a range as part of the definition of Pseudomonas follow. If Pseudomonas was described as containing organisms having DNA with not less than 57 nor more than 70 moles \% guanine + cytosine (GC), all the aerobic pseudomonads encountered within this study would be included. Aerobic pseudomonads which are at present classified in other genera, but which might be assigned to the genus Pseudomonas, have DNA base compositions which fall within these suggested limits. Analyses have been published for representatives of Xanthomonas (Colwell \& Mandel, 1964a; De Ley \& Van Muylem, 1963), for the polarly flagellate Acetomonas (Gluconobacter), by De Ley \& Schell (1963), for Comamonas (Leifson \& Mandel, 1966; Sebald \& Véron, 1963), for Vibrio sensu lato (Sebald \& Véron, 1963; Colwell \& Mandel, 1964a), and all have GC contents well within the suggested range. The hydrogenomonads likewise have DNA base compositions within this range (data to be published). No information 
is available for representatives of Alginomonas, Cellulomonas and Cellvibrio. The use of the above suggested range of GC contents as diagnostic for Pseudomonas would exclude Methanomonas if the value for the single culture examined in this study should prove to be representative of the genus.

The morphological and physiological definition does not exclude the newly proposed genera Campylobacter (Sebald \& Véron, 1963) and Bdellovibrio (Stolp \& Starr, 1963). The 30-34 moles \% GC content of the DNA of Campylobacter was one of the chief criteria used by Sebald \&Véron (1963) in assigning Vibrio fetus and V.bubulus to the new genus. Drs Mandel, Starr \& Baigent will report elsewhere that representatives of Bdellovibrio have DNAs of low GC content and thus may be excluded from Pseudomonas.

The marine bacterium Flavobacterium piscicida Bein has been found to be polarly flagellate (Hansen, Ingebritsen \& Weeks, 1963) and hence reassigned to the genus Pseudomonas by Buck, Meyers \& Leifson (1963). Mandel, Weeks \& Colwell (1965) have shown that 20 strains of this species have DNA of 44.5 moles $\%$ GC. The above proposed limit of GC contents would exclude this species from the genus Pseudomonas. The computer taxonomic study of Hansen, Weeks \& Colwell (1965) showed this phenon to bear a 67-70\% similarity to certain Pseudomonas species. The species of $\boldsymbol{P}$ seudomonas bearing the greatest similarity to $\boldsymbol{P}$. piscicida were the strains of Lysenko (1961) labelled $\boldsymbol{P}$. geniculata and $\boldsymbol{P}$. atlantica; my doubts about the identity of these cultures are expressed above. No disservice to the taxonomy of Pseudomonas will be done by further chequering the career of the chromogenic ichthyotoxigenic marine bacterium by its exclusion from the genus. This bacterium, as well as the low-GC organisms $\boldsymbol{P}$. cruciviae and $\boldsymbol{P}$. atlantica, should be compared with the marine vibrios of similar base compositions (Colwell \& Mandel, $1964 b)$.

If the genus $\boldsymbol{P}$ seudomonas is then defined, in part, as having species whose GC contents range from 57 to 70 moles $\%$, how does this compare with other taxonomic units? The compilation of DNA base compositions of Marmur et al. (1963a) lists members of the genus Bacillus as having a still broader range (35-51\% GC), and members of Corynebacterium range from 53 to $59 \%$ GC. Mandel, Bergendahl \& Pfennig (1965) established that the green sulphur bacteria of the genus Chlorobium have at least 51-58\% GC contents of their DNAs. Caulobacter species range from 62 to $67 \%$ GC, and the related Asticcacaulis has DNA of $55 \%$ GC (Poindexter, 1964). Lactobacillus species are reported as having DNAs of 35-53\% GC, by Suzuki \& Kitahara (1964).

The family Enterobacteriaceae has representatives whose DNA GC contents are as low as 39 moles \% (Proteus) and as high as $59 \%$ (Serratia). The actinomycetes appear to be more uniform and, though usually accorded higher taxonomic rank, GC contents apparently range from 65 to $75 \%$ GC. In summary, the suggested range of GC contents for definition of the genus Pseudomonas cannot a priori be accounted as either too narrow or too broad. The decision on the propriety of using DNA base composition as part of a generic definition is then based upon the uniformity provided to the assemblage contained within the taxon.

One major test of the genetic and perhaps phylogenetic relatedness of the aerobic pseudomonads has been initiated by De Ley \& Friedman (1965). They found substantial hybrid formation of DNA molecules extracted from various species of 
$X$ anthomonas, Pseudomonas and acetic acid bacteria, with the DNA of $\boldsymbol{X}$. pelargoni. Indeed, the degree of relatedness expressed by these estimates of hybrid formation are surprisingly high.

Marmur et al. (1963a) suggested that the limits of episomal transfer, based upon experiences with the Enterobacteriaceae, could define a family. The apparent episome found in Pseudomonas stutzeri may provide a similar test for the pseudomonads. Mandel \& Rownd (1964) showed that Aeromonas liquefaciens and Serratia marcescens contain satellite DNA matching Escherichia coli DNA in base composition but present in only one-tenth the proportion of satellite to main DNA found in $\boldsymbol{P}$. stutzeri. The physiological definition excludes Aeromonas and Serratia from Pseudomonas but the notion persists that Aeromonas is related to Pseudomonas and may serve as an evolutionary link between the enteric bacteria and pseudomonads (De Ley, 1964 b; Lysenko, 1961). Needless to say, neither molecular hybridizations nor genetic tests have been performed which would lend support to this view; the task is a formidable one.

The valuable and expert technical assistance of Mrs Janet Bergendahl is gratefully acknowledged. Mrs Theresa Kwan provided expert assistance in statistical analysis; her co-operation and that of the Department of Biomathematics of this institution is greatly appreciated. I express my deep appreciation to the many colleagues who supplied the bacterial cultures cited in the text and to Dr S. H. Hutner, who first acquainted me with the aerobic pseudomonads and the works of the 'Dutch School'.

The gift of an analytical ultracentrifuge and accessories by the Mr and Mrs T. N. Law Foundation is gratefully acknowledged.

\section{REFERENCES}

American Type Culture Collection, Catalogue of Cultures (1964). 7th ed. Rockville, Maryland. Buck, J. D., Meyers, S. P. \& Leifson, E. (1963). Pseudomonas (Flavobacterium) piscicida Bein comb.nov. J. Bact. 86, 1125.

Campbell, L. L. \& Postgate, J. R. (1965). Classification of the spore-forming sulfatereducing bacteria. Bact. Rev. 29, 359.

Colwell, R. R. \& MANDEL, M. (1964a). Adansonian analysis and deoxyribonucleic acid base composition of some Gram-negative bacteria. $J$. Bact. 87, 1412.

Colweli, R. R. \& Mandel, M. (1964b). Base composition of deoxyribonucleic acid of marine and nonmarine vibrios deduced from buoyant-density measurements in cesium chloride. J. Bact. 88, 1816.

Delafield, F. P., Doudoroff, M., Palleroni, N. J., Lusty, C. J. \& Contopoulos, R. (1965). Decomposition of poly- $\beta$-hydoxybutyrate by pseudomonads. J. Bact. $90,1455$.

De LeY, J. (1964a). Effect of mutation on DNA-composition of some bacteria. Antonie van Leeurwenhoek, 30, 281.

De Ley, J. (1964b). Pseudomonas and related genera. A. Rev. Microbiol. 18, 17.

De Ley, J. \& Friedman, S. (1965). Similarity of Xanthomonas and Pseudomonas deoxyribonucleic acid. J. Bact. 89, 1306.

De Ley, J. \& Schell, J. (1963). Deoxyribonucleic acid base composition of acetic acid bacteria. J. gen. Microbiol. 33, 243.

De Ley, J. \& van Muylem, J. (1963). Some applications of deoxyribonucleic acid base composition in bacterial taxonomy. Antonie van Leeurwenhoek, 29, 344.

DEN Dooren DE Jong, L. E. (1926). Bijdrage tot de kennis van het mineralisatie proces. Rotterdam: Nijgh and van Ditmar. 
Dworkin, M. \& Foster, J. W. (1956). Studies on Pseudomonas methanica (Söhngen) nov. comb. J. Bact. 72, 646.

Elrod, R. P. \& Braun, A. C. (1942). Pseudomonas aeruginosa: its role as a plant pathogen. J. Bact. 44, 633.

Fisher, R. A. (1925). Application of Student's distribution. Metron, 5, 90.

Frontali, C., Hill, L. R. \& Silvestri, L. G. (1965). The base composition of deoxyribonucleic acids of Streptomyces. J. gen. Microbiol. 38, 243.

Hansen, A. J., Ingebritsen, A. \& Weeks, O. B. (1963). Flagellation of Flavobacterium piscicida. J. Bact. 86, 602.

Hansen, A. J., Weeks, O. B. \& Colwell, R. R. (1965). Taxomony of Pseudomonas piscicida (Bein) Buck, Meyers, and Leifson. J. Bact. 89, 752.

Hirota, Y. \& Irjima, T. (1957). Acriflavine as an effective agent for eliminating F factor in Escherichia coli $\mathrm{K}-12$. Nature, Lond. 180, 655.

Holloway, B. W. (1955). Genetic recombination in Pseudomonas aeruginosa. J. gen. Microbiol. 13, 572.

Holloway, B. W. \& Monk, M. (1959). Transduction in Pseudomonas aeruginosa. Nature, Lond. 184, 1426.

Joshi, J. G., Guild, W. R. \& HANDler, P. (1963). The presence of two species of DNA in some halobacteria. J. mol. Biol. 6, 34.

Lanni, F. (1960). Genetic significance of microbial DNA composition. Perspectives Biol. Med. 3, 418.

LEE, K. Y., WAHL, R. \& BARBU, E. (1956). Contenu en bases puriques et pyrimidiques des acides désoxyribonucléiques des bactéries. Ann. Inst. Pasteur, 91, 212.

LEIFson, E. \& MANDEL, M. (1966). The DNA base composition of a flagellar mutant of Comamonas terrigena ATcC 8461. Antonie van Leeuwenhoek, 32 (in the Press).

Lysenko, O.(1961). Pseudomonas-an attempt at a general classification. J. gen. Microbiol. 25, 379.

MANDEL, M. (1962). The interaction of spermine and native deoxyribonucleic acid. J. mol. Biol. 5, 435.

Mandel, M., Bergendahl, J. \& Pfennig, N. (1965). Deoxyribonucleic acid base composition in the genus Chlorobium. J. Bact. 89, 917.

MANDEL, M. \& Rownd, R. (1964). DNA base composition in the Enterobacteriaceae: an evolutionary sequence? In Taxonomic Biochemistry and Serology, Ed. by C. A. Leone, p. 585. New York: Ronald Press.

Mandel, M., Weeks, O. B. \& Colwell, R. R. (1965). Deoxyribonucleic acid base composition of Pseudomonas piscicida. J. Bact. 90, 1492.

MARMur, J. (1961). A procedure for the isolation of deoxyribonucleic acid from microorganisms. J. mol. Biol. 3, 208.

Marmur, J. \& Doty, P. (1962). Determination of the base composition of deoxyribonucleic acid from its thermal denaturation temperature. J. mol. Biol. 5, 109.

Marmur, J., Falkow, S. \& Mandel, M. ( 1963a). New approaches to bacterial taxonomy. A. Rev. Microbiol. 17, 329.

Marmur, J., Rownd, R. \& Schildkraut, C. L. (1963). Denaturation and renaturation of deoxyribonucleic acid. Prog. Nucleic Acid Res. 1, 231.

Marmur, J., Seaman, E. \& Levine, J. (1963b). Interspecific transformation in Bacillus. J. Bact. 85, 461.

Poindexter, J. S. (1964). Biological properties and classification of the Caulobacter group. Bact. Rev. 28, 231.

Redfearn, M. S., Palleroni, N. J. \& Stanier, R. Y. (1966). A comparative study of Pseudomonas pseudomallei and Bacillus mallei. J. gen. Microbiol. 43, 293.

Schildkraut, C. \& Lifson, S. (1965). Dependence of the melting temperature of DNA on salt concentration. Biopolymers, 3, 195.

Schildkraut, C. L., Marmur, J. \& Doty, P. (1962). Determination of the base composition of deoxyribonucleic acid from its buoyant density in CsCl. J. mol. Biol. 4, 430.

Sebald, M. \& Véron, M. (1963). Teneur en bases de l'ADN et classification des vibrions. Ann. Inst. Pasteur, 105, 897. 
Silvestri, L. G. \& HrLl, L. R. (1965). Agreement between deoxyribonucleic acid base composition and taxometric classification of Gram-positive cocci. J. Bact. 90, 136.

Stanier, R. Y., Palleroni, N. J. \& Doudoroff, M. (1966). The aerobic pseudomonads : a taxonomic study. J. gen. Microbiol. 43, 159.

Stolp, H. \& StaRr, M. P. (1963). Bdellovibrio bacteriovorus gen. et sp.n., A predatory, ectoparasitic, and bacteriolytic micro-organism. Antonie van Leeurwenhoek, 29, 217.

Suzuki, J. \& Kitahara, K. (1964). Base compositions of desoxyribonucleic acid in Sporolactobacillus inulinus and other lactic acid bacteria. J. gen. appl. Microbiol. 10, 305.

van Niel, C. B. \& Allen, M. B. (1952). A note on Pseudomonas stutzeri. J. Bact. 64, 413. 